\title{
【特 集：災害と廃棄物対策】
}

\section{自然災害における災害廃棄物の発生特性と 処理方策に関する調查研究}

一廃裹物学会研究委員会自主研究の中間報告——

島 岡 隆 行*

【要 旨】阪神・淡路大震災は多くの人命を奪い，構造物に甚大な被害を及ぼした。同時に，この地震 によって 1,850 万 ton にも及ぶ災害廃衰物が発生している。震災直後の災害廃衰物の処理にあたっては, 被災地からの搬出方法, 仮置き場や最終処分場での対応，焼却，リサイクルのための破砕・選別方法な ぞ，様々な点において試行錯誤が繰り返された。また，損壊家屋の解体に伴い発生する廃裹物量の膨大 さが改めて認識されるに至った。これらのことを教訓に，廃棄物学会研究委員会のあとにおいて，自然 災害における廃裹物処理の在り方について, 若手の廃棄物学会員を中心に調查研究（自主研究）を行う こととなった。

本報は復興初期における阪神・淡路大震災の現地調查, および各メンバーが在住地で発生した災害事 例について行った現在までの調查結果を紹介し, 自主研究活動の中間報告とするすのである。

キーワード : 自然災害, 阪神・淡路大震災, 災害廃棄物, 処理処分

1.はじめに

先般の阪神・淡路大震災では，十数秒間の地震によっ て 1,850 万 ton とその地方から平常時に発生する廃衰物 量の数年間分にあ相当する膨大な廃棄物が発生し，その 処理にはまだまだ長き時間を要するすのと思われる。こ のような未曾有の地震を教訓に, 廃棄物学会研究委員会 のあとにおいて, 自然災害における廃棄物（災害廃棄 物) 処理の在り方について調查研究 (自主研究) を行う こととなった。そこで自主研究グループでは，地震のみ ならず，大雨，台風といった気象災害，さらには異常渴 水に伴うごみ質の変化やその清掃工場への影響などあ調 查研究の範嚋に含め, 若手の廃车物学会員を中心とした 表 1 に示すメンバーで，本年 5 月下旬の阪神・淡路大震 災現地調查をすって研究を開始しした。また，自主研究 メンバーは, 各自, 在住地で発生した災害事例について,

原稿受付 1995. 8.25

* 福岡大学工学部土木工学科 助教授

連絡先： ₹ 814-80 福岡市城南区七隈 8-19-1
災害廃棄物の発生状況ならびに処理の経緯を取りまとめ, 災害の種類とその災害廃棄物の特徵, 処理における課題 の抽出を目下行っているところである。

しかし，調查を開始して 2 ヶ月あまりと間がなく，十 分な成果が得られていないのが現状であり，本報では文 献に見られる災害廃裹物の知見を紹介するとともに，阪 神・淡路大震災の復興初期における現地調查, および現 在までにメンバーが行った調查結果をかいつまんで報告 させて頂くこととする。

表 1 研究委員会自主研究メンバー

\begin{tabular}{|c|c|c|}
\hline 氏 & 名* & 属 \\
\hline \multirow{7}{*}{ 代表 } & 大迫政浩 & 国立公衆衛生院廃棄物工学部 \\
\hline & 大槻俊和 & 仙台市役所環境局施設部施設課 \\
\hline & 金谷 健 & 滋賀県立大学環境科学部環境計画学科 \\
\hline & 島岡隆行 & 福岡大学工学部土木工学科 \\
\hline & 東條安匡 & 北海道大学工学部衛生工学科 \\
\hline & 前野祐二 & 鹿児島工業高等専門学校 \\
\hline & 渡辺信久 & 大阪市立環境科学研究所 \\
\hline
\end{tabular}

*廃裹物学会会員の若手（40 歳未満）の中で, 自然災害が高 い頻度で発生している地方の方を選出。 


\section{2. 災害廃棄物に関する従来の研究}

災害廃棄物の調查研究を開始するにあたり, 文献検索 （JICST）を行った。検索したキーワードとその文献件 数を表 2 に示す。なお，被検索期間は，1981 年 1 月よ り 1995 年 1 月とした。「災害廃棄物」による検索では文 献が見あたらず，その知見は極めて少ないといえる。 「地震災害」に関しては，高レベルの放射性廃棄物を眝 蔵するための構造物の耐震解析や振動解析に関するもの で大半が占められていた。その他の文献も，(1)パッカー 車の炎上など, 廃棄物の収集に伴う火災や労働災害, (2) 選別処理センターでの爆発事故, 清掃工場の灰バンカー での水素爆発，ごみピットへのパッカー車の転落事故な ど, 中間処理施設での災害, (3)古夕イヤ (大分県山光村, カナダ,イギリスでも発生), 廃材の火災など, 廃棄物 の眝留・保管に伴う災害に関するものであり, 本調查研 究に参考となる文献は少なかった。以上のようなことか ら出力を行った文献（299 件）で有用なものは, わずか 数件1-7)にすぎなかった。ここでは, 興味深い文献をい くつか紹介させて頂く。

国内の文献では, 1982 年の『都市清掃』特集「特殊 環境での清掃事業」) に, 水害, 洪水で発生した災害廃 裹物の処理対策事例が揭載されており, 今回の阪神・淡 路大震災にも役立ったであろう知見が見受けられる。ま た, 建設省土木研究所は, 長崎水害 (1982 年), 山陰水 害（1983 年）を対象に路上障害物の除去方法に関する 調查研究2)をまとめている。豪雨により自動車, ヘドロ, 流木, 水害ごみ, さらには高圧電線が道路に流し出され 路上障害物となっている。長崎水害を例にあげると, 被 害を受けた自動車は約 7,600 台であり, 路上に放置され た自動車は 1,204 台に達したとしている。これは, 水害 において顕在化する問題ではあるが, 地震, 風害におい ても類似の事態が生じ, 災害後の復旧は道路の確保から 始められるといっても過言ではなく, 貴重な知見が記さ れている。さらに, 風水害のあとには流不塺芥がダム眝

表 2 文献検索の結果

\begin{tabular}{|c|c|}
\hline キーワード & 件 \\
\hline 廃 棄 物 & 137,250 \\
\hline 固形廃棄物 & 29,872 \\
\hline 災害廃棄物 & 0 \\
\hline 災 害 & 49,878 \\
\hline 地震災害 & 20,350 \\
\hline 火＼cjkstart事 & 1,866 \\
\hline 災 害 $\times$ 固形廃棄物 & $145^{*}$ \\
\hline 地震災害 $\times$ 廃 棄 物 & $127^{*}$ \\
\hline 火 事 $\times$ 廃 裹 物 & $27^{*}$ \\
\hline
\end{tabular}

*出力を行った文献。

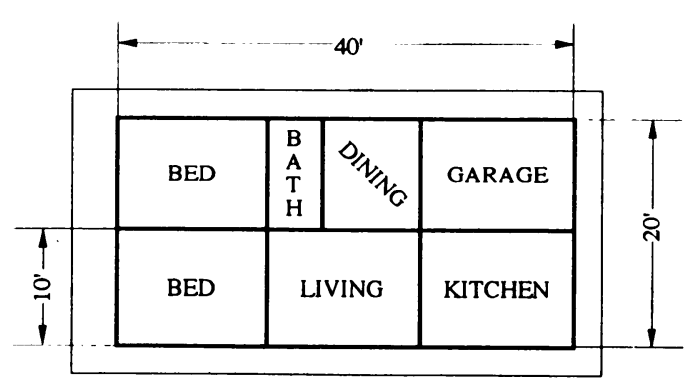

図 1 廃棄物量の原単位を算出した家屋

表 3 家屋解体に伴う廃棄物量の原単位

(unit : Tons)

\begin{tabular}{lrrrrrr}
\hline \multicolumn{1}{c}{ Structure and Roof Type } & Glass & Wood $\begin{array}{r}\text { Con- } \\
\text { crete }\end{array}$ & $\begin{array}{r}\text { Roofing } \\
\text { Material }\end{array}$ & $\begin{array}{c}\text { Total } \\
\text { Weight }\end{array}$ \\
\hline Concrete Structure with asphalt roof & 0.77 & 2.26 & 26.80 & 6.07 & 35.13 \\
Concrete Structure with fiberglass shingle roof & 0.77 & 2.26 & 26.80 & 4.75 & 33.81 \\
Concrete Structure with clay tile roof & 0.77 & 2.26 & 26.80 & 7.92 & 36.98 \\
Wood structure with asphalt roof & 0.77 & 14.00 & 0.00 & 6.07 & 20.83 \\
Wood structure with fiberglass shingle roof & 0.77 & 14.00 & 0.00 & 4.75 & 18.76 \\
Wood structure with clay tile roof & 0.77 & 14.00 & 0.00 & 7.92 & 21.93 \\
\hline
\end{tabular}

水池に流入し, この流木が船舶の安全航行を妨害し, 取 水口スクリーンを目詰まらせ発電などに支障を与えるの を始め, 洪水時, 水の流れの障害となり二次災害の原因 ともなる。黒田ら゙3)，流木の木炭化による再資源化を 試み, 樹種に関係なく経済的に高い発熱量 $(7,600 \sim$ $7,800 \mathrm{cal} / \mathrm{kg}$ ）を有する木炭ができあがり，しかも良質 な木酢液, 木灰が得られたとしている。

国外の文献では, カナダの Hubert ら ${ }^{4)}$ が火災後の枯 れた立木のエネルギー利用に対する経済的試算および然 焼実験を行っている。また, Berrin ら5)はハリケーン （アンドリュウ）の建物被害の結果発生した災害廃棄物 の発生量を推定している。被害デー夕から建物被害の著 しかった $5 つ の$ 地域を抽出し, それぞれの地域について 建築部材構成から災害廃裹物の発生量を算出している。 その様子を図 1 および表 3 に示し，小さな家屋 1 軒から 発生する災害廃棄物量 (原単位) が求められている。災 害発生後の迅速な災害廃棄物発生量の推定は対策を立て る上で重要であり, 極めて興味深い文献といえる。

また, 災害, 震災, 火事, 台風, 洪水などのキーワー ドで新聞記事の検索も行っており, 今後, 整理を行うつ ありである。

[担当：島岡隆行]

\section{3．近年に発生した災害と災害廃棄物}

既に述べたように, 本自主研究においては地震災害の みならず, 台風, 津波, さらには異常渴水, 火山噴火を あ調査研究の対象とし, 過去に発生した災害を調查する ことにより, 自然災害時の廃棄物の処理方法について検 
討するなど，廃棄物処理方策に関する取りまとめを行お うとするものである。災害事例の調査内容として，(1)災 害の発生状況, (2)災害復旧・復興の状況, (3)災害廃棄物 の発生状況, (4)廃棄物関連施設の被害状況, (5)災害廃裹 物の処理状況をあげている。また，検討事項として，(1) 災害廃棄物の発生量の算定, (2)災害廃衰物の性状, (3)災 害時の有害物, 危険物の取り扱い方法, (4)災害廃裹物の 搬出方法, (5)搬出, 搬入道路の確保, (6)建設業組合, 解 体業組合との連携，(7)災害廃衰物の再利用，(8)仮置き 場・最終処分場の体制，(9)市民への広報活動，(10)救援活 動の在り方, (11)災害廃棄物の広域処理, (12)災害後の一般 廃棄物の処理方法, (13)自治体の災害への備え方, (14)防災 マニュアルと防災訓練，などを考えている。

\section{1 地 震}

（1）阪神・淡路大震災（1995 年）

阪神・淡路大震災については, 被害を受けた自治体は あとより各分野による調查が実施され, 情報の収集・整 理がなされつつある。被害状況や復興に関する情報の中 で, 神戸市の情報は周辺他都市に比較して多いと感じら れることから, 西宮市, 宝塚市, 伊丹市, 芦屋市, 大阪 市などの都市形態, 人口規模や災害の被害程度が異なる 中小都市を重点的に調查を実施することを予定しており， このことにより阪神・淡路大震災の全貌がより明らかに なり, 今後の地震災害発生に対して有益な知見が得られ ると考えている。

自主研究グループでは, 震災後 4 ヶ月が経過した本年
5 月 25 日に，第一回目の災害廃棄物処理現地調查を実 施し,さらに 7 月 11 日には大阪市の災害廃棄物の処理 状況についても調查を行っている。災害廃裹物の調査に あたっては, 廃裹物の量・質, 処理フローなどが経過時 間とともに刻々と変化するために，災害発生直後からの 長期的な調查を行うことが重要であり，この点は橋梁・ 道路といった構造物の被害調查とは大きく異なる点であ ると考える。そこで, 自主研究グループでは, 今後とも 継続的に現地調查を行う予定である。

本節では, 第 1 回災害廃棄物処理現地調查結果の報 告8)をさせて頂く。調查地点は, 図 2 に示す 6 ヶ所であ る。

○神戸市（ポートアイランド 2 期工事用地）

神戸市では災害廃裹物を大まかに木質系とガレキに分 けて災害地から仮置き場へ搬出している。木質系の仮置 き場は布施畑，淡河，複合の 3 ヶ所に仮置きするととも に，深江港（第 4 工区）および神戸港からポートアイラ ンドに海上輸送し，仮置きしている。また，ガレキは灘 浜, 長田の 2 所の積み出し基地から海上輸送し, 一部 は木質系と同じポートアイランドに仮置きしていたが, 4 月以降は摩耶埠頭，六甲南などに直接海面埋立てをし ている。 5 月 20 日現在で,この仮置き場には 575,100 ton の災害廃棄物が搬入されていた。

木質系廃裹物は, $10 \mathrm{ha}$ の用地に高さ $5 \mathrm{~m}$ 程度で延々 と野積みされ，その周囲には油の浮いた濁った浸出水が 発生していた。その野積みされた災害廃棄物の中で数台 の重機が選別作業を行っていた。その後, 浸出水につい

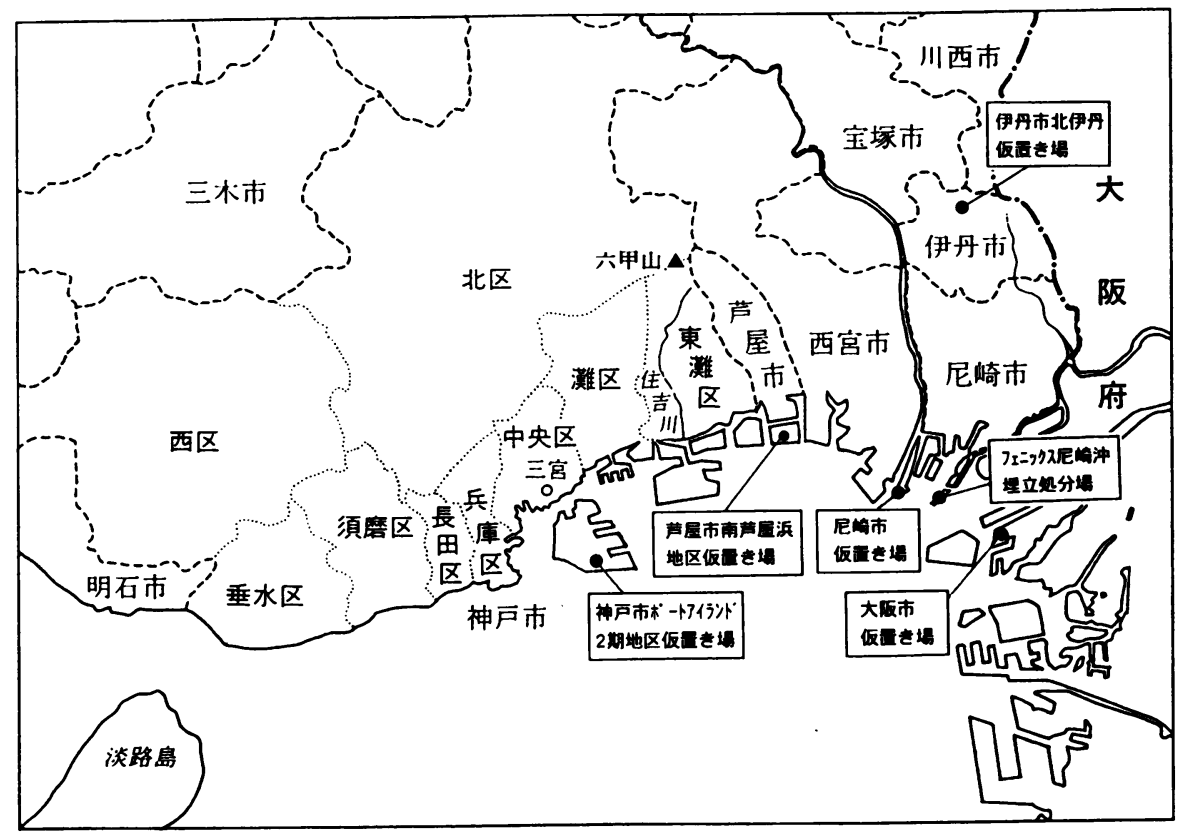

図 2 第 1 回災害廃衰物処理現地調査地点 


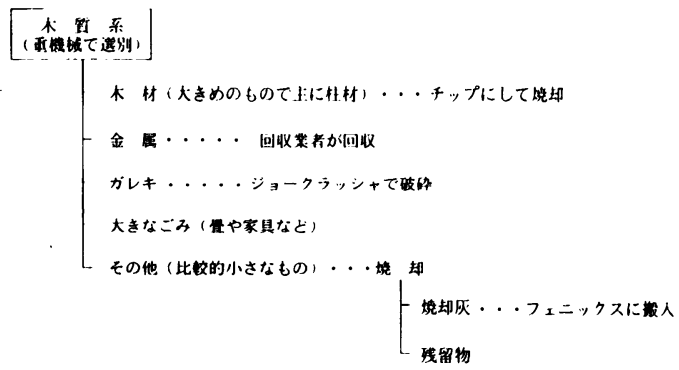

図 3 ポート:アイランド 2 期地区での木質系廃棄物の 処理フロー

ては, 仮置き場周囲に側溝を掘り, 活性炭で浸出水の処 理を行っているとのことである。困 3 には, ポートアイ ランド 2 期工事用地での木質系廃裹物の処理フローを示 している。搬入された廃棄物は木材, 金属, ガレキ, そ の他の大きなごみを重機で選別し, 残ったものについて はふるいで土砂が取り除かれている。木質系廃棄物と呼 ばれているが, 実際の木質系の割合は19\%（重量比） と少なく, 処理に苦慮されていた。選別された木材は破 砕機でチップ $(10 \sim 20 \mathrm{~cm})$ にされる。このチップは 仮設の小型焼却炬（=40 ton $\times 2$ 基）で焼却されてい た。また，この小型焼却炉の近くに，200 ton/日の焼 却炉が 2 基建設予定とのことであった。

ここで, 神戸市と今回調查を行った後述する周辺都市 （自治体）との比較を行うと, 災害廃棄物の発生量は他 都市に比べてかなり多いが, 他自治体より処理作業は遅 れているように思われた。10月の大規模炉の稼働を 待って, 処理が本格化するとのことであった。また, 災 害廃裹物の分別搬入が, 他の自治体と比較して厳密に行 われていないとの印象を受けた。［担当：前野祐二］

○芦屋市（南芦屋浜地区仮置き場）

芦屋市の被害は, 全建物 15,390 棟の内, 全壊 4,661 棟, 半壊 3,943 棟, 一部損壊 4,447 棟, その他 2,339 棟 で あった（4月 17 日現在）。建物解体の申込件数 4,083 件 の内， 1,726 件が解体されていた（4 月 15 日現在）。罹 災証明の発行数から判断して, 最終的には全棟数の 3 分 の 1 にあたる 5,100 棟が解体されるものと推定される。

災害廃棄物の発生量が, 解体家屋数之原単位を用いて 推定されている。なお，表 4 の原単位は，直接その数値 を聞きだしたものではなく, 解体家屋数, 設定標準面積 と推定発生量からさかのぼって計算したものである。こ の原単位は，様々な文献值をもとに予測されたとのこと である。

木造家屋については, 解体時の実測を試みたところ 60 ton / $100 \mathrm{~m}^{2}$ であったとのことで, 推定値 53.5 ton/ $100 \mathrm{~m}^{2}$ は妥当な值といえる。実際には,「家屋の解体以
表 4 芦屋市での家屋解体に伴う廃棄物発生量の原単位

\begin{tabular}{|c|c|c|c|c|c|c|}
\hline \multirow[b]{2}{*}{ 種 類 } & \multirow{2}{*}{$\begin{array}{c}\text { 解体家屋数 } \\
\text { （楝） }\end{array}$} & \multirow{2}{*}{$\begin{array}{l}\text { 標準面積 } \\
\left(\mathrm{m}^{2} / \text { 棟 }\right)\end{array}$} & \multicolumn{2}{|c|}{ 推定発生量 } & \multicolumn{2}{|c|}{ 原単位 } \\
\hline & & & $\begin{array}{l}\text { 廃木材 } \\
\text { (ton)** }\end{array}$ & $\begin{array}{c}\text { ガレキ } \\
(\text { ton)*** }\end{array}$ & $\begin{array}{c}\text { 廃木材 } \\
\text { (ton } / \mathrm{m}^{2} \text { ) }\end{array}$ & $\begin{array}{c}\text { ガレキ } \\
\left(\text { ton } / \mathrm{m}^{2}\right)\end{array}$ \\
\hline 木 造 & 5,000 & 100 & 93,500 & 174,000 & 0.187 & 0.348 \\
\hline $\mathrm{RC}$ & 100 & $2,000^{*}$ & 23,400 & 290,800 & 0.117 & 1.454 \\
\hline 家屋以外 & - & - & 184,000 & 200,000 & - & - \\
\hline 計 & - & - & 300,900 & 664,800 & - & - \\
\hline
\end{tabular}

* $\mathrm{RC}$ : 平均面積 20 戸 $\times 100 \mathrm{~m}^{2} /$ 戸

** 廃木材の密度は 0.5 ton $/ \mathrm{m}^{3}$

:*** ガレキの密度は 1.3 ton $/ \mathrm{m}^{3}$

外に由来する廃衰物」の量が非常に大きく，その理由と して原単位の中に門, 塀, 家屋の基礎が入っていないた めと一応の説明はされているが, 隣接する都市からの流 入によるものあ少なくないと考えられる。

南芦屋浜地区仮置き場は兵庫県企業局所有地であり, ヨットハーバーを有するような高級住宅地の建設予定地 であるところを 4 ha 借地していた。仮置きの山の高さ は平均 $10 \mathrm{~m}$, 一部 $20 \mathrm{~m}$ 以上の山になっていた。搬入廃 棄物量は $7,000 \sim 8,000$ ton/日で, 1994 年度に搬入さ れた廃裹物は, 廃木材 199,400 ton, ガレキ226,800 ton である。搬入車両の割合は，木質系 $30 \%$ ，ガレキ $10 \%$, ミンチ（混合状態のあの） $60 \%$ である。ミンチの搬入 量を減らすために，ミンチ状で般入されたものについて は待ち時間を故意に長く, 分別されているものについて は待ち時間を短くするという方策を用いていたが, 災害 地からの廃棄物の搬出が進み, 待ち時間が短くなるにし たがって、この方策も効果がなくなったとのことである。 解体面積によって解体費用が支払われる状況（廃率物の 状態は問わず，すなわち分別してあ見返りがない。）で は, 解体業者側に分別に時間をかけるよりあ少しであ早 く解体しょうとの心理か働くものと考えられる。

震災直後は木質系を野焼きしていたが 4 月一杯で中止 している。ただし，野焼きを中止しても，直ぐには埋火 せず，その後約 10 日間むくすぶったとのことである。

野焼きによる焼却量（2 月 15 日〜 4 月 30 日）は 35,700 ton $(800$ ton/日，木質系発生量の約 $12 \%$ と推定され る。）で，焼却残渣の熱灼減量は $20 \sim 30 \%$ である。野 焼きを中止してからの木質系は，リサイクル（柱材はパ ルプ原料へ）および焼却炉での焼却が行われている。焼 却炉は，市の現有炉，仮設炉，他都市および民間への委 託の計 13 炉を確保しており，予定焼却量は 265,000 ton （木質系発生量の約 88\%）である。ガレキは約 440,000 ton（ガレキの約 66\%）を尼崎沖埋立処分場へ搬出し， その他は民間への引き取りおよび再利用を行う予定との ことであった。ミンチは約 3 ha の土地に破砕・選別施 


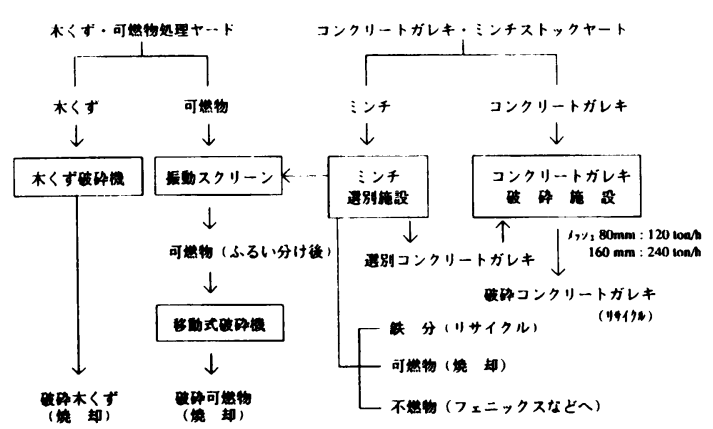

図 4 芦屋市の災害廃裹物処理フロー

設を設置し，図４に示すフローにしたがって処理するた めの処理施設の設置工事が行われていた。

[担当：渡辺信久]

\section{○尼崎沖埋立処分場}

平常の処分場への般入量は $2,500 〜 3,000$ ton/日であ るが, 震災後は $6,000 〜 7,000$ ton/ 日であり, ガレキを 主体とする災害廃棄物は, 4,500 4,800 ton/ 日搬入さ れている。また，野焼きの残渣が 100 ton/日程度搬入 されており，宝塚市からの搬入（総量約 1,000 ton）は 終了し, 今後, 芦屋市のものが搬入予定であった。安定 型区画へ投入されているガレキの中には木くずが混入し ており, 浮遊する木くずは回収船によって回収されてい た。なお, 安定型ストックヤードには最高で 20,000 ton 貯まったとのことであるが, 調査時点では 7,000 ton 程 度であった。

尼崎基地に隣接する尼崎市の公園は，市の仮置き場と して利用されていた。調查当日も野焼きが行われており， 野狫きによる煙は少し黒く, 風向きによっては海側にも 陸側にあ流れていた。この野焼きは，5月一杯で中止を するとのことであった。野焼きはやむを得ないとの見方 ああるが, 今後, 野焼きに対する評価（全面否定, 条件 付き否定, 全面肯定) は, 今後の検討課題である。

現地調査の後に, 大阪湾広域臨海環境整備センターへ, 災害廃栽物搬入状況を問い合わせた。その結果は下記の 通りであった ( 5 月 28 日現在)。

1) 尼崎沖埋立処分場への搬入（累計 668,060 ton)

$\begin{array}{lr}\text { 宝塚市 } & 160,219 \text { ton } \\ \text { 伊丹市 } & 106,374 \text { ton } \\ \text { 尼崎市 } & 83,878 \text { ton } \\ \text { 神戸市 } & 66,568 \text { ton } \\ \text { 川西市 } & 20,313 \text { ton } \\ \text { 西宮市 } & 4,252 \text { ton } \\ \text { 芦屋市 } & 657 \text { ton } \\ \text { 播磨町 } & 198 \text { ton } \\ \text { 阪急電鉄 } & 97,119 \text { ton }\end{array}$

近畿地方建設局（阪神高速） 46,276 ton

阪神電鉄

44,156 ton

$J R$ 西日本

38,050 ton

2 ）泉大津沖埋立処分場への搬入（累計 251,669 ton）

$\begin{array}{lr}\text { 芦屋市 } & 98,253 \text { ton } \\ \text { 豊中市 } & 82,827 \text { ton } \\ \text { 池田市 } & 30,307 \text { ton } \\ \text { 神戸市 } & 17,663 \text { ton } \\ \text { 莰木市 } & 13,562 \text { ton } \\ \text { 大阪市 } & 5,210 \text { ton } \\ \text { 西宮市 } & 3,847 \text { ton }\end{array}$

3) 総合計 919,729 ton $\left(566,028 \mathrm{~m}^{3}\right)$

[担当 : 金谷 健]

○伊丹市（北伊丹仮置き場）

調査を行った伊丹市の仮置き場は, 市内に 7 ヶ所ある 内の一つで, 通称「敷紡跡地」と呼ばれている。

この仮置き場に震災の廃棄物が搬入され始めたのは, 地震発生の 2 日後の 1 月 19 日からである。当初, 伊丹 市では，個人が搬入して来る廃裹物を「一般廃衰物」と して無料でこの北伊丹仮置き場で引き取り，業者搬入の 廃裹物を「産業廃棄物」として有料で別の管理場（神 津）にて引きとるというシステムをとった。伊丹市には， 豊中市と構成する一部事務組合（豊中市伊丹市クリーン ランド）の焼却炉（既設： 225 ton/日 $\times 3$ 炬と新設 : 195 ton/日×1炬）が存在するが, 地震により緊急停 止, 2 本の煙突の内 1 本が倒壊するという被害を被って いる。豊中市伊丹市クリーンランドは, 震災発生直後 （1月17日）に4炉とも緊急停止，1月 21 日に 3 号炉 (225 ton/日) 運転開始, 1 月 23 日に 4 号炉 (195 ton/ 日), 2 月 27 日に 1,2 号炉（ともに 225 ton/日）の 順で運転が再開されている。

1 月 27 日，伊丹市は仮置き場を 7 所に増設し，す ベての災害廃棄物をこれらで引き受けることとした。4 月 28 日に自衛隊が管理する $2 つ$ つ仮置き場が閉鎖され たことで, 調查時は残りの 5 つの仮置き場で対応してい た。他都市では, 小数の大規模な仮置き場もしくは処分 場へ廃裹物を搬入する車両による大渋滞という問題に苦 慮していたが, 仮置き場を散在させた伊丹市では搬入車 両が自然に分散し, 渋滞の問題はおこらなかったようで ある。また，野焼きについても航空機の走路（大阪国際 空港）に近いことから不可能であり, 初期の非常に早い 時点で必然的にリサイクルを処理手段として選択してい る。そのため, 開始当初から, 徹底分別を試み, 他都市 の分別形態が主に木質系, ガレキ, ミンチ（混合）とい う 3 種程度であるのに対し, 伊丹市は, シバ材（此較的 小さな木片), 柱材 (木材の柱), 石材, ミンチ (木材と 
土砂，ガレキの混合)，不燃ごみ，大型家具類，畳，金 属スクラップと詳細に分別することを搬入業者に要求し ている。時には業者にトラックから手おろしをさせてま で，分別の徹底をはかったということである。

平常, 伊丹市は可燃ごみ, 不然ごみ, 粗大ごみの 3 種 分別であり，高度なリサイクルシステムとしてのノウハ ウを有していたわけではない。狭い仮置き場が必然的に 早期搬出を指向させ, 分別, リサイクルを促進させたも のと推察される。さらに, 処理に携わる様々な業者（総 合建設業, 廃菓物処理業) の協力体制が非常に効果的に 発揮されたことも，このような分別・リサイクルシステ ムが築かれた背景としてあげられる。

以下に, 分別された廃裹物の処理フローを図 5 に示し, 個別に記述する。

1) シバ材：破砝機（タブグラインダー）によりチップ 化し, 焼却。木材搬入量の内, 約 8 割がシバ材, 残り の 2 割が柱材ということである。

2) 柱材: 専門の業者が，木材の中から柱材を抜き取り, パルプ化するために搬出している。

3) 石材: クラッシャーを用いて粉砕, $30 \sim 40 \mathrm{~mm}$ の 碎石状にする。得た砕石は業者に無料で提供, 整地な どの資材として使用されている。処理コストとして 1 ton 当り 1,400 円の值段がかかる゙, 尼崎冲埋立処分 場に搬出する場合（1 ton 当り 5,000 円）に比較して, かなり低コストで有効に機能していると伊丹市では考 えている。

4) ミンチ:木くず, がれき混じりの土のことである。 このままでは産業廃棄物扱いとなることから，振動ふ

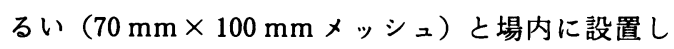
た水槽を用いた浮遊選別を使用して，木材，石材，残 渣とに分別する。ふるいを通過した残渣は，投入量の

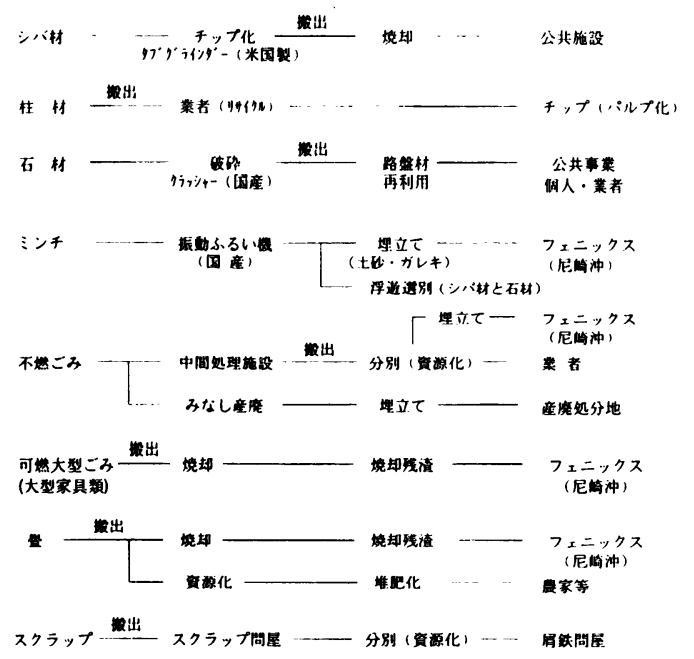

図 5 伊丹市の災害廃裹物処理フロー
$65 \%$ 程度で, 尼崎沖埋立処分場に搬出される。浮遊 選別で浮いた木材（約 15\%）は再びシバ材のライン へ戻され，沈んだ石など（約 20\%）は石材ラインに 戻される。

5 ）不燃ごみ：伊丹市収集の家庭系不燃ごみである。一 旦引き受け, 中間処理施設へと般出する。一部は「み なし産廃」として, 産業廃裹物処分場へと般出されて いる。

6 ）大型家具類：焼却施設へ送り, 焼却残渣は尼崎沖埋 立処分場で処分される。

7) 畳: 焼却施設へ送るほか, 最近では業者の協力のも とコンポスト化に成功している。コンポストの需要は 多いとのことであった。材もコンポストにできるが， 防蟻剤の心配があるので採用していない。

8 ）金属スクラップ: スクラップ問屋に搬出し，そこで 分別, 最終的にはくず鉄問屋へと流れる。

震災発生 2 ヶ月後の段階で, 伊丹市災害廃棄物の総発 生量は,

$\begin{array}{lr}\text { コンクリート } & 284,000 \text { ton } \\ \text { 木 } & 126,000 \text { ton } \\ \text { 金属 } & 22,000 \text { ton } \\ \text { プラスチック } & 6,000 \text { ton }\end{array}$

合計 438,000 ton と見積られている。この推定の根拠は 次の通りである。

$\begin{array}{ll}\text { 伊丹市における解体家屋数 約 } 2,700 \text { 棟 } \\ \text { 一部損壊の修理棟数 } & \text { 約 } 50,000 \text { 棟 }\end{array}$

一棟当りの床面積は古い家屋が多いため $150 \mathrm{~m}^{2}$ （他都 市は $100 \mathrm{~m}^{2}$ 前後) とし, 床面積 $1 \mathrm{~m}^{2}$ あたり 0.5 ton (0.5 ton の内訳は, 木 0.15 ton, コンクリート 0.35 ton である。他都市は, $\quad 0.7 \sim 0.8$ ton $/ \mathrm{m}^{2}$ ) の廃棄物が発生 するとしている。また, 一部損壊については, 床面積 $100 \mathrm{~m}^{2}$ とし, その 10 分の 1 に相当する面積, すなわち $10 \mathrm{~m}^{2}$ 程度が損壊分であるとしている。これについては 当初 20 分の 1 の床面積としていたが, その後 10 分 1 に 修正したということである。

調查時点で, 災害廃衰物の量は, 伊丹市の各仮置き場 に搬入後外部へ搬出されたものが約 16 万 ton, 仮置き 場に残されている量が約 6 万 ton で合計 22 万 ton と見 積あられている。災害廃棄物総量の推定値が約 44 万 ton であることから, 今後残りの 22 万 ton の廃栽物が 発生することとなるが, 現在の搬入状況から推察して, 今後 13 万 ton 前後, すなわち, 総量として 35 万 ton 程度で終わるのではないかと推定している。

なお，一日の搬入量は震災後暫くは約 2,000 ton （1,000 台）であったが, 調查時点（ 5 月下旬）では, 約 1,000 ton（500 台）と半減しており, 担当者によると後 
半年で伊丹市における災害廃棄物の処理は終了するので はないかとのことである。

また，般入される災害廃衰物の質は, 震災直後は, 瓦, 壁土などが主体であったものが，最近ではコンクリート ガレキ, 新建材などに推移し, 解体される家屋が被害の 大きかった古い木造家屋から，一部損壊の文化住宅に なってきているためとのことである。[担当：東條安匡]

大阪市

7 月 11 日に, 阪神・淡路大震災で発生した大阪市の 災害廃棄物の仮置き場の現地調查を行っている。現場は, 大阪ガスより借り受けた, 北港の約 1 ha の土地（以前 は，石炭のストックヤードとして使用されていた。）で ある。大阪市では, 約 800 棟 (大半が木造家屋) の解体 が行われ, 中間処理を含めて民間委託で行っている。仮 置き場での作業は, 特に大きな選別機械を設置せず, 重 機のみで対応している。その反面, 搬入廃棄物のチェッ クを厳しく行っており, ミンチ状態での搬入を最低限に 抑えている。仮置き場での作業は, 搬入可燃物から柱材 （リサイクル）と畳（ひきちぎった後に焼却）を取り出 し, 残りを清掃工場へ搬出している。搬入不燃物につい ては, スクラップ（リサイクル）を取り出し, 残りを埋 立地（泉大津沖埋立処分場之北港処分場）へ搬出してい る。

廃率物発生量の予測をたてる際に，住宅産業解体処理 業連絡協議会やハウスメーカーからの廃裹物発生原単位 （表 5 参照）が参考にされている。今回の災害廃裹物処 理での大阪市での実績は, 平均延床面積 $129 \mathrm{~m}^{2}$ /, 廃棄物発生量 $96 \mathrm{~m}^{3} /$ 戸であり, 参考値と良く一致して いた。

災害廃裹物の処理体制について種々の議論がなされた 結果, 図6に示すような構成になっている。業務は大阪 府産業廃棄物処理協会に委託しており，2 月 22 日より 受け入れを開始している。

搬入券（マニフェスト伝票）は，大阪市都市整備局が 搬入量を予測して，環境事業局名で施工業者（元請け）

表 5 木造住宅の解体に伴う廃棄物発生量の原単位

\begin{tabular}{|c|c|c|c|c|c|c|}
\hline \multirow[b]{2}{*}{ 廃裹物の種類 } & \multicolumn{4}{|c|}{ 解体延床面積 $\left(792 \mathrm{~m}^{2}\right)^{*}$} & \multicolumn{2}{|c|}{ 原単位 } \\
\hline & $\begin{array}{l}\text { 重 量 } \\
(\mathrm{kg})\end{array}$ & $\begin{array}{c}\text { 重量乘 } \\
\text { (\%) }\end{array}$ & $\begin{array}{l}\text { 容 積 } \\
\left(\mathrm{m}^{3}\right)\end{array}$ & $\begin{array}{c}\text { 容積率 } \\
\text { (\%) }\end{array}$ & $\begin{array}{c}\text { 重 量 } \\
\left(\mathrm{kg} / \mathrm{m}^{2}\right)\end{array}$ & $\begin{array}{c}\text { 容 積 } \\
\left(\mathrm{m}^{3} / \mathrm{m}^{2}\right)\end{array}$ \\
\hline く ず & 61,392 & 19.3 & 299.7 & 50.8 & 77.5 & 0.378 \\
\hline コンクリート破片 & 123,621 & 58.9 & 101.8 & 17.2 & 156.1 & 0.129 \\
\hline ガラス及び陶磁器くず & 64,002 & 20.1 & 86.2 & 14.6 & 80.8 & 0.109 \\
\hline 金属くず & 6,915 & 2.2 & 30.2 & 5.1 & 8.7 & 0.038 \\
\hline 廃プラスチック類 & 1,399 & 0.4 & 12.6 & 2.1 & 1.8 & 0.016 \\
\hline & 55,690 & 17.5 & 45.8 & 7.8 & 70.3 & 0.058 \\
\hline 畳 & 4,935 & 1.6 & 13.9 & 2.4 & 6.2 & 0.018 \\
\hline 計 & 317,954 & 100.0 & 590.2 & 100.0 & 401.5 & 0.745 \\
\hline
\end{tabular}

* 8 棟 $\left(99 \mathrm{~m}^{2} /\right.$ 棟) の延床面積

出典：住宅産業解体処理業連絡協議会

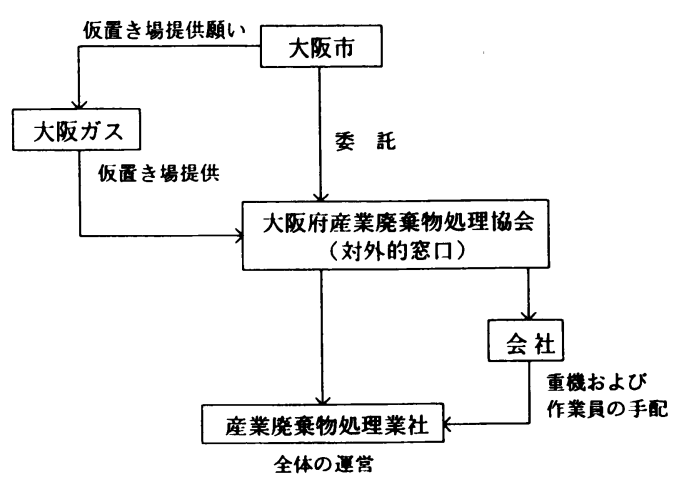

図 6 大阪市における災害廃棄物の処理体制

に発行している。期限つきで, 余分の搬入券の返却を求 めるものである。搬入区分は，基礎・土間部分を除いた 可燃物と不然物の 2 種類である。搬入ごみの素性確認に は, 搬入券をもとにする以外, 口頭での質問 (町名, 番 地など）や内容物の確認（手紙類があれば確認できる） あ行われている。また, 解体現場からの廃裹物のみを受 け入れることになっており, 業者による中継所から運ば れるあのは受け入れていない。専門家の目では, 中継所 からの搬入物はすぐに見抜けるとのことであった。

搬入台数はピーク時には150台/日であった。7月 初旬は $70 \sim 80$ 台/日であるが, 今後鉄筋コンクリー 卜家屋の解体が始まるので, 概ね 100 台/日になるも のと予想されている。なお，仮置き場の受付時間は，午 前 9 時より午後 4 時 30 分まで（作業は午後 5 時まで） であり, 土曜・日曜日も業務が行われている。

災害廃裹物は可燃物と不然物に解体現場で分別して搬 入することになっている。ミンチ状の災害廃棄物につい ては, 強力な指導が行われた。解体現場へ持ち帰らせて 選別させる, あるいは仮置き場入り口で手選別させるな どを行った。その結果， 4 月中旬にミンチ状の災害廃衰 物の搬入はほぼなくなったとのことである。ただし，解 体現場が非常に狭いなどの事情で, ミンチ状廃衰物しか 搬入できない事例もあり，その場合は所定の手続きを とった上で，受け入れることにしている。

現場での運営を行っている委託業社の中の一人は, 産 業廃尧物処理業・解体業を 20 年間（現場 14 年, 管理 6 年の経歴) 行ってこられており, 非常に経験豊富である。 この方によると今回の廃裹物で問題となったミンチ発生 は, 日頃, 解体をしていなかった「にわか解体屋」が, 無計画に建物を潰したためと指摘している。解体開始時 に計画を立て，それにしたがって作業することにより， ミンチ状災害廃棄物の発生は防げ，分別によって作業時 間が延びるかというと，経験の浅い者であればそうであ 
るが，慣れている作業者ならば，効率よく分別解体がで きるそうである。

[担当: 渡辺信久]

(2) 三陸はるか沖地震 $(1994 \text { 年 })^{9)}$

1994 年 12 月 28 日午後 9 時 19 分頃, 八戸市の東方沖 $200 \mathrm{~km}$ を震源とするマグニチュード 7.5 の地震が発生 した。地震の摇れは北海道および東北地方の広範囲にお よび, 各地で有感地震が観測され，八戸市では震度 6 の 烈震を記録した。この地震により，2名が死亡，一般家 屋など建築物 111 棟が全壊するなどの被害が生じた。ま た，本震に引き続き，1995 年 1 月 7 日午前 7 時 37 分頃, 岩手県沖を震源とするマグニチュード 6.9 の余震が発生 し, 八戸市では震度 5 を記録した。この地震による死者 はなかったものの, 建築物 20 棟が全壊するなどの被害 が生じた。

地震により市内全域で家屋などの損傷被害があり, 特 にガラス, 陶磁器類の破損被害が著しく, 集積場はこれ らの不燃ごみが氾濫し, 通常の収集体制では処理できな い状態となったため, 収集車両を增車し, 早期収集に努 めた。地震発生から20日間（収集車を增車して対応し た期間）に排出されたごみの量は, 可燃ごみが 3,172 ton で 1993 年度の約 $10 \%$ 增であったのに対し, 不燃ご みは 1,972 ton で 1993 年度の 3 倍程度の量となった。 ごみの排出量の経年变化は, 当時横ばい傾向であったこ とから, 增加分がすべて地震による災害廃棄物と考えら れる。

また, 地震発生後 5 ヶ月間の災害一般廃棄物（減免扱 い自己搬入分）の各施設への搬入状况を表 6 に示す。こ の表から, 清掃工場および粗大ごみ処理場には地震発生 後 1,2 ヶ月間に多く搬入されており, 埋立処分場には 地震後 1 ヶ月間に集中して搬入されていることが読みと れる。地震により破損した家具や家電品などはごみとし て排出され, 相当量が災害一般廃棄物として施設へ直接 持ち込まれたと考えられるが, 地震発生後の 1995 年 1 月に粗大ごみの定期収集が行われ，かなりの量の災害廃

表 6 三陸はるか沖地震で各施設へ般入された

\begin{tabular}{|c|c|c|c|c|c|c|c|c|c|c|}
\hline \multirow{3}{*}{ 年・月 } & \multicolumn{2}{|c|}{ 可燃物 } & \multicolumn{2}{|c|}{ 不 } & K & 燃 & \multicolumn{2}{|l|}{ 物 } & & \multirow[b]{2}{*}{ 郭 } \\
\hline & $\begin{array}{l}\text { 八 } \\
\text { 清损 }\end{array}$ & $\begin{array}{r}\text { 戸 } \\
\text { 帚工場 }\end{array}$ & $\begin{array}{l}\text { 筍引 } \\
\text { こみ }\end{array}$ & $\begin{array}{l}\text { I粗 大 } \\
\text { 処理場 }\end{array}$ & & $\begin{array}{l}\text { 狗沢 } \\
\text { l分場 }\end{array}$ & & 、計 & & \\
\hline & 件数 & 重量 & 件数 & 重量 & 件数 & 重量 & 件数 & 重量 & 件数 & 重量 \\
\hline 1994.12 & 5 & 410 & 5 & 300 & 74 & 11,460 & 79 & 11,760 & 84 & 12,170 \\
\hline 1995.1 & 27 & 7,520 & 33 & 5,330 & 310 & 375,380 & 343 & 380,710 & 370 & 388,230 \\
\hline 2 & 11 & 6,950 & 26 & 8,610 & 102 & 119,860 & 128 & 128,470 & 139 & 135,420 \\
\hline 3 & 5 & 2,120 & 4 & 1,150 & 87 & 129,780 & 91 & 130,930 & 96 & 133,050 \\
\hline 4 & 2 & 670 & 0 & 0 & 98 & 140,680 & 98 & 140,680 & 100 & 141,350 \\
\hline 5 & 8 & 1,400 & 1 & 40 & 80 & 118,920 & 91 & 118,960 & 99 & 130,360 \\
\hline 計 & 58 & 19,070 & 69 & 15,430 & 751 & 896,080 & 820 & 911,510 & 878 & 930,580 \\
\hline
\end{tabular}

注 1) 1994 年 12 月は, 29 日からの值を示す。

注 2 ）件数は延件数である。
棄物がこのとき排出されたと思われる。

廃裹物の質は, 住宅家屋が 100 棟以上も全壊するよう な震度 6 の烈震に見舞われたことから, 建物自身の被害 の有無に関わらず, 住宅内の家具, 家電品, 嶑磁器類, ガラスなどの多くが壊れ，ごみとして排出された。また， 建物の損壊に伴い, ブロック, 柱, 壁といったいわゆる 建設廃棄物む多く排出された。

廃裹物の処理処分は, 通常, 可燃ごみは, 直営, 委託 により収集し, 清掃工場で焼却している。不然ごみ, 粗 大ごみは, 委託により収集し, 粗大ごみ処理施設で破砕, 選別処理を行っている。焼却灰, 選別残渣, 土砂ガレキ など（一部産業廃棄物を含む）は，埋立処分をしている。 それに対して, 災害時においてはガラス, 陶磁器類など の不燃ごみの排出量が通常の 3 倍程度に增加したため, 12 月 29 日以降, 翌年 1 月 14 日まで, 通常の委託収集 車両の他に増車して早期収集に努めた。しかし, それで あ収集が追いつかないため, 直営者も可燃ごみ収集後, 不燃ごみ収集の支援にあたった。なお，この間に収集し た不燃ごみは,すべて埋立処分とした。

焼却施設などの処理施設への被害は, なかったようで ある。また，近隣都市との協力体制も，特に見られない。 [担当：大柣俊和]

（3）北海道南西沖地震（1993 年）

1993 年 7 月 12 日午後 10 時 17 分, 北海道南西沖を震 源とするマグニチュード 7.8 の地震が発生した。地震直 後に, 奥尻島および北海道の日本海側に巨大な津波が来 襲し, 多くの犠牲者を出すとともに, 沿岸域の住居, 港 湾などの構造物に多大な被害をむたらした。被災町村は 道南地方 60 市町村におよび, 被害総額は 1,747 億円に あのぼる。

この地震により大きな被害を被ったのは, 奥尻町を筆 頭に道南地方の日本海側に位置する島牧村, 大成町, 北 檜山町, 瀬棚町などの町村である。これらの町村はいず れも津波によって大きな被害を被っている。さらに, 道 南地域の, 上磯, 長万部町についてあ液状化により大き な住居被害が生じている。

最む被害の大きかった奥尻町（全半壊 525 戸，火災に より消失約 190 戸, 廃自動車約 600 台）では, 津波に よって壊滅状態となった青苗地区を中心に，津波により 破壊された家屋, 陸に打ち上げられた漁船, 家財道具, 木片, 自動車などが陸上に散乱し, さらに, 港内, 沖に まで家の残骸, 転覆した船などが流され, 浮遊している 状況にあった。通常の奥尻町の清掃事業形態は可燃ごみ, 不燃ごみ・粗大ごみの分別収集で, 可然ごみは焼却, 不 燃ごみ・粗大ごみは直接埋立という形態をとっているが, 地震によって, 焼却施設も被災, 通常の業務形態は到底 
とれない状況にあった。地震の翌日より, 町が中心と なって建設業者の協力のもと, 散乱したガレキの撤去が 開始された。陸上に散乱した可燃ごみを数ヶ所に集め, たき火程度の野焼きで処理し, 海に転落, 流されたもの は起重機船により回収した。不燃性のコンクリートガレ キ, 鉄スクラップ, 廃自動車, FRP 製漁船, 野焼きの 残渣などは，島内に急きょ確保した処分場にて直接埋立 処分した。緊急時のため, 行方不明者の捜索之, そのた めのガレキの撤去などに重点がおかれ，処分場に搬入さ れるガレキの計量, あしくは搬入車両台数の記録をして いる余裕はなかったということであり, 廃棄物の量に関 しては全く不明ということであった。北海道保健環境部 の推定によれば, 約 47,000 ton の災害廃棄物の発生が あったということである。町の収集業務が開始されたの は地震後 10 日ほどしてから, 焼却施設が正常に稼働し たのは約 3 ヶ月後の 1993 年 10 月ごろからである。

奥尻島の対岸であり，同様に津波による大きな被害を 被った島牧村（家屋全半壊 36 戸，一部破損 52 戸，床上， 床下浸水 121 戸, 被災車両 73 台, 被災漁船 244 隻, 全 半壊した車庫, 物置など 92 戸) あ同じょうな状況に あった。島牧村は平常時は島牧村, 寿都町, 黒松内町で 構成する南部後志衛生施設組合にて清掃業務が行われて いるが, 地震の後, 地震と津波によって発生した膨大な 量の廃裹物は, その大半を村内に所有する粗大ごみ用の 処分場に搬入し, 直接埋立て処分している。村の集計に よると, 地震によって発生した廃棄物の総量は約 5,000 $\mathrm{m}^{3}$ ということである。その内の約 $20 \%$ の $1,000 \mathrm{~m}^{3}$ が 南部後志組合に搬入されている。組合側では, 災害廃棄 物はすべて処分場に搬入させ, 可燃性のものは一部は処 分場内で野焼きし, その他の大半は, 直接埋立処分した ということである。災害によって発生した廃棄物, 特に 津波により破壊された構造物のガレキは, 散乱している ために重機を使って回収することになるが,この場合,

木材, コンクリート，鉄などがすべて一緒に回収される ため, その後の分別は困難で，焼却炬に投入することも できず, 直接埋め立てるより方法がなかったということ である。

大成町, 北檜山町, 瀬棚町, 今金町で構成する北部檜 山衛生センター組合では, 組合が主体となって, 災害廃 萧物の収集・撤去にあたっており, 地震翌日より特別に 手配したトラック，重機などで散乱した廃棄物の回収を 開始している。この地域も津波による被害が大きく,こ れらの 4 町で全半壊家屋が約 240 戸, 一部損壊家屋が 533 戸，床上床下浸水が 145 戸という被害を被っている。 ここでも，焼却炉と煙突の耐火煉瓦が脱落するなど，廃 萧物処理施設に被害が生じ，平常時とは異なったシステ
ムを採用せざるをえない状況に陥っている。地震後の 10 日間は災害廃棄物, 一般のごみすべてを直接埋立処 分した。その後, 焼却炉を応急復旧させ，一般可燃ごみ の焼却を開始するが，完全に正常に復旧したのは，5 月後の 1993 年 12 月からである。般入される災害廃棄物 はすべて埋立処分している。この組合では，4 町から収 集した災害廃棄物をすべて計量しており，1993 年の 7 月から10月までに搬入された災害廃椠物の量は約 14,000 ton ということである。

津波の被害ではないが, 液状化により大きな住居被害 を被った上磯町でも住居の解体材が多く搬入される事態 となる。地震による解体材はすべて無料で受け入れてい る。ここでも他の例に漏れず，災害廃棄物はすべて埋立 処分したということである。

調查にあたった日は南西沖地震のちょうど 2 年後の 1995 年 7 月 12 日であったが, 被災地域は現在も復旧工 事が続いており, その工事によって排出される建設廃材 などあ多く，それらを引き受けている自治体，組合では， 末だに廃衰物量の増大は続いているということであった。

[担当 : 東條安匡]

(4) 釧路沖地震（1993 年）

1993 年 1 月 15 日午後 8 時 6 分発生, 震源は釧路沖で

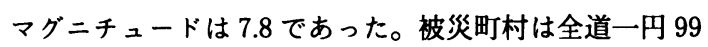
市町村におよび被害総額は約 955 億円に達する。震度は 震源に近い釧路市で震度 6 を観測した。全半壊家屋は 307 戸, 一部破損家屋が 5,311 戸に及ぶが, 冬季で土㙵 が凍結していたことああり, 地震の規模に比べて, 被害 は幸いにあ少なかった。

災害によって顕著に廃棄物の量などが変化し, 自治体 の清掃事業に影響が及んだのは釧路市のみであった。そ の他, 釧路町においてす, 若干の廃棄物量の増大が確認 されるが, 町としては, 臨時の収集を数回行った程度で あった。家屋の倒壊は釧路市で最も多く全壊 42 戸, 半 壊 191 戸，一部破損 2,427 戸であった。

釧路市においては地震の翌日より直接搬入される家屋 の解体材が増大した。市では地震による解体材はすべて 無料で受け入れる方針をとった（1993 年 1 月 16 日〜同 年 12 月 31 日)。平常時においても釧路市は全量埋立処 分という体制をとっている。そのため, 特に市として特 別な対応はしていない。しかし, 無料引き受けした災害 廃棄物は上記の期間でほぼ 20,000 ton に達したとみら れている。

[担当 : 東條安匡]

(5) 宮城県沖地震災害 $(1978 \text { 年 })^{10)}$

宮城県沖地震災害による被害状況は文献 1 ）の特集記 事に記述されている。森郷埋立地に搬入された量は, 仙 台市の内部資料から, 表 7 の通りである。災害廃棄物は, 
表 7 宮城県沖地震での森郷埋立地への廃棄物搬入量

(単位: $\mathrm{kg}$ )

\begin{tabular}{|c|c|c|c|c|c|}
\hline \multirow{2}{*}{ 年・月 } & \multicolumn{2}{|c|}{ 搬入総量 } & \multicolumn{2}{|c|}{ 震災による無料取扱量 } & \multirow{2}{*}{$\begin{array}{c}\text { 割 合 } \\
\%\end{array}$} \\
\hline & 台 数 & 搬入量 & 台 数 & 搬入量 & \\
\hline 1978. 6 & 8,401 & $18,301,300$ & 6,599 & $11,953,620$ & 78.3 \\
\hline 7 & 7,479 & $10,128,780$ & 2,396 & $5,550,330$ & 54.8 \\
\hline 8 & 7,301 & $11,991,920$ & 1,993 & $7,192,700$ & 60.0 \\
\hline 9 & 5,988 & $10,140,510$ & 1,409 & $5,831,800$ & 57.5 \\
\hline 10 & 5,640 & $8,003,790$ & 1,114 & $3,638,600$ & 45.5 \\
\hline 11 & 4,723 & $6,475,930$ & 682 & $2,589,300$ & 40.0 \\
\hline 12 & 6,563 & $6,978,660$ & 484 & $1,478,500$ & 21.2 \\
\hline 1979. 1 & 3,040 & $3,324,930$ & 283 & 607,000 & 18.3 \\
\hline 2 & 3,626 & $4,401,830$ & 591 & $1,080,000$ & 24.5 \\
\hline 3 & - & - & 399 & $1,305,000$ & - \\
\hline 計 & - & - & 15,910 & $41,226,850$ & - \\
\hline
\end{tabular}

注) 1979.4.10 現在

表 8 仙台市のごみ処理量の推移

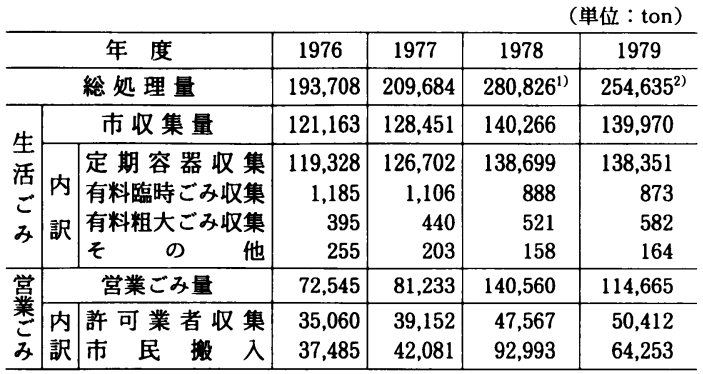

1） 1978 年度は震災廃棄物 48,341 ton（市収集 5,120 ton, 許 可業者収集 1,994 ton, 市民搬入 41,227 ton）を含む。

2）1979 年度は震災ごみ 7,721 ton（市民搬入）を含む。

罹災証明を受けた被災者が搬入したもので，無料扱いと なっている。

また，清掃事業概要によれば, 1978 年度の災害廃裹 物の発生量は, 市収集分 5,120 ton, 許可業者収集分 1,994 ton，市民搬入分 41,227 ton の計 48,341 ton， 1979 年度の発生量は，市民般入分 7,721 ton である。1976 年 度から 1979 年度のごみ処理量の推移を表 8 に示す。な お，建設廃棄物などの産業廃棄物は，その一部を 1979 年 6 月まで仙台市が所有する森郷埋立地で処分していた が，小鶴沢処理場（宮城県環境事業公社所有）が同年 7 月に開設されたのに伴い, その処分先が変更された。こ のため, 1979 年度の災害廃栽物の排出量は, 市のデー タから正確に把握できない。

廃棄物の質については，詳細な資料は残されていない が, 初期の段階では, 地震により破損した食器などや家 財品（市収集が主），倒壊ブロックなどのガレキ類（市 民搬入，業者収集）が多く排出され，その後は家屋の解 体や修理に伴う廃裹物（市民搬入）が主要なものになっ たものと考えられる。

処理施設の被害状況については, 1978 年度中に復旧 したが，一部の改善工事は次年度以降に対処した。具体
的には，非常用発電機の冷却系などを各設備共通となっ ている冷却系統から切り離し独立させ，非常時に発電機 の起動を確実に行えるようにした。 [担当：大柣俊和]

\section{2 台 風}

（1）台風第 10 号大雨洪水災害 $(1986 \text { 年 })^{10)}$

台風 10 号が, まだ本州の南海上にある 1986 年 8 月 4 日朝から, 東北南部の福島県から雨が降り出し, 尽頃ま でに雨域は東北南部全域に広がった。午前中はまだ雨は それほど強くなく，仙台市で一時やや強く降ったほかは， 1 時間に数 $\mathrm{mm}$ 程度であった。夜半前から東北南部で 雨足が強まり, 福島, 宮城の両県では 1 時間に $20 \mathrm{~mm}$ から $30 \mathrm{~mm}$ の強い雨になり, 台風から変わった低気圧 が東北地方に最も接近した夜半過ぎから 5 日未明にかけ て, 宮城, 福島の両県では 1 時間 $30 \mathrm{~mm}$ から $40 \mathrm{~mm}$ の強い雨が数時間続いた。宮城県内の雨の状況をみると， 夜半頃からの強い雨は, 県の中・南部の平野部で降って おり, 仙台市では 5 日午前零時から午前 9 時までの間に $265 \mathrm{~mm}$ あの雨が集中して降った。特に, 午前 3 時から 4 時までに $40 \mathrm{~mm}$ の雨が降った。仙台市の降り始めか ら雨が止むまでの総雨量は $402 \mathrm{~mm}$ を記録し、これは 1948 年 9 月に襲来したアイオン台風に匹敵するすので ある。

この雨により, 市内の各地において床上・床下浸水, がけ崩れ, 道路冠水, 農地冠水などの多くの被害が発生 した。この原因としては, 今回の台風, 大雨が, (1)台風 が日本の南岸で低気圧に変わったこと, (2)低気圧の進行 速度が遅かったこと, (3)雨台風であったこと, (4)平野部 中心に大雨が降ったこと，(5)強雨期間が長く続いたこと， などの特徵があり末曾有の $402 \mathrm{~mm}$ あ降水があった ことに加え, 主な浸水地区が雨水排除施設としての下水 道の未整備区域であったこと, 市街地の主な浸水地区が 雨水排除を農業用排水施設に頼っていたこと, 市街地か らの急激な出水が排水施設の能力を越えていたこと, 岩 盤と表土の間に水脈が発生したことなどがあげられる。

台風 10 号による仙台市の災害状況は, 幸いにも死者 は出なかったが, 床上, 床下浸水などによる住宅の被害 10,084 戸，農作物の被害 3,300 haにのぼった。また, 清掃施設も大きな被害を受け，被害の最も大きかった市 東部に位置する主力工場の一つである小鶴清掃工場は運 転不能に宿り, 復旧に 1 ヶ月以上も要する被害を受けた。

豪雨により, 仙台市の東部の浸水地域の中心に, 冠水 した畳, 家具, 食品などの災害廃棄物が 8 月 6 日から 8 月 31 日の間に 9,241 ton が排出された。この畳は, 前 年同期の排出量の約 5 割にあたる。これらのごみは浸水 家屋から排出されたものがほとんどであり, 水害という 
特殊性から，排出された時期は水が引いてからの短期間 に集中し，8月 6 日から 13 日の 8 日間に全災害廃棄物 の約 $71 \%$ にあたる 6,539 ton が各処理施設に搬入され た。初期の排出状況を表 9 に示す。

仙台市の災害廃棄物としては, 家屋浸水による畳や家 具などの一般ごみと食品などの営業ごみが排出された。 これらのごみは焼却施設, 埋立地に運ばれ処理されたが, 焼却施設ではごみ中の水分の上昇, 埋立地では液状食品 による浸出水の BODなどの上昇がみられ，焼却炬や排 水処理施設の運転に少なからず影䅧を与えた。埋立地浸 出水水質の経月変化をそれぞれ表 10 に示す。埋め立て 後,およそ 5 ヶ月にわたり BODなどが異常に高い值を 示した。

廃棄物の通常の処理処分は，一般廃棄物にういては一 般廃裹物の処理計画に基づき行っている。収集について は，一般家庭の日常生活から排出されるごみは週 3 回ス テーション方式により，粗大ごみは年 2 回申し込みによ り集積所ごとに排出されたものを計画的に収集している。 事業者の事業活動に伴って排出されるごみは, 自ら市の 処理施設に搬入するか，一般廃棄物処理業者に収集を依 頼することとしている。また，処理については，焼却可 能ごみは小鶴, 今泉の両清掃工場で焼却処理, 粗大ごみ は今泉粗大ごみ処理施設で破砕処理, 有価物の回収, 残 灰および焼却不適ごみは石積埋立処分場で埋立処分して いる。なお, 空き缶, 空き瓶類は, 市が委託する業者が 週 1 回収集し,この業者の施設において選別を行い有価 物を回収している。

災害時の対応を仙台市では災害廃裹物に対応するため, 8 月 6,7 日の新聞に, 冠水した畳, 家具類は石積埋立

表 9 台風 10 号による災害廃棄物の初期排出状況

\begin{tabular}{|c|c|c|c|c|}
\hline \multirow{2}{*}{ 月・日 } & \multicolumn{3}{|c|}{ 収 集 量 (ton) } & \multirow{2}{*}{ 搬入台数（台） } \\
\hline & 災害廃棄物 & 通常ごみ & 計 & \\
\hline $8 / 6$ & 272 & 1,266 & 1,538 & 824 \\
\hline 7 & 1,107 & 737 & 1,844 & 995 \\
\hline 8 & 1,168 & 972 & 2,140 & 1,052 \\
\hline 9 & 1,362 & 668 & 2,030 & 992 \\
\hline 10 & 436 & 47 & 483 & 250 \\
\hline 11 & 668 & 1,118 & 1,786 & 934 \\
\hline 12 & 766 & 789 & 1,555 & 824 \\
\hline 13 & 760 & 745 & 1,505 & 851 \\
\hline 計 & 6,539 & 6,342 & 12,881 & 6,722 \\
\hline
\end{tabular}

表 10 災害廃棄物を処分した埋立地 浸出水質の経時変化

\begin{tabular}{lrrrrrrrrr}
\hline & \multicolumn{1}{c}{ 年・日・日 } & 1986 & & & & & \multicolumn{4}{c}{ (単位: $\mathrm{mg} / \ell$ ) } \\
\hline 項目 & $7 / 8$ & $8 / 20$ & $9 / 10$ & $10 / 8$ & $11 / 5$ & $12 / 3$ & $1 / 27$ & $2 / 5$ & $3 / 11$ \\
\hline $\mathrm{Cl}^{-}$ & - & 8.3 & 7.1 & 6.6 & 6.6 & 6.6 & 6.6 & 6.5 & 6.7 \\
$\mathrm{BOD}$ & 1,270 & 2,000 & 1,900 & 2,300 & - & 2,200 & 868 & 1,300 & 860 \\
$\mathrm{COD}$ & 708 & 290 & 930 & 270 & 310 & 190 & 118 & 240 & 295 \\
$\mathrm{SS}$ & 50 & 190 & 190 & 410 & 1,370 & 550 & 2,760 & 770 & 4,200 \\
\hline
\end{tabular}

処分場に，食品などの生ごみは今泉清掃工場に搬入する こと，搬入できない場合は町内会などでとりまとめて市 に収集を申し込むことなどの内容の広報を揭載し，混乱 の起こらないように周知徹底させるとともに, 早朝収集, 搬入締め切り時間の延長, 土曜日の平常勤務体制などで 災害廃裹物の処理にあたり，手数料も無料とした。

小鶴清掃工場の被災により, 今泉清掃工場の予備炉を 急きょ立ち上げ焼却処理にあたったが，搬入されるごみ に焼却が追いつかずピットへのごみの滞留が著しくなっ たことから，通常のごみの一部を近隣市町（旧泉市，利 府町, 富谷町）に委託して焼却または埋立てにより処理 した。

清掃施設の内, 最も被害を受けた小鶴清掃工場では, 床上浸水 $35 \mathrm{~cm}$ で地下および 1 階部分にある蒸気ター ビン, 空気圧縮機，ポンブ類，制御盤などの重要機器類 が水没, 冠水した。幸い, 清掃工場では気象情報などか ら豪雨により浸水する可能性があると判断し立ち下げ作 業に入っており, 雨水の流入時点ではすでに埋火状態に あり，被害がボイラーなどに及ぶ大事には至らなかった。 その他の施設では, 石積埋立処分場搬入路方面の一部崩 壊や収集車両の冠水などがあったものの, 処理処分に影 響する被害は少なく, 当日から災害廃棄物の収集, 処理 処分を行った。

仙台市の主力工場の 1 つ小鶴清掃工場が被災し, 焼却 施設は今泉清掃工場のみとなったため, 予備炉を使い処 理能力を一日 600 ton とし焼却処理を行った。しかしな がら, 災害廃棄物の搬入量が処理能力を大きく上回った ため, 炉のオーバーホール時などの処理について協力関 係にあった近隣の市町に協力を要請し, 8 月 8 日から 28 日の間, 旧泉市, 富谷町の焼却場で家庭ごみを焼却 した。また，前年度に埋め立てを終了した利府町にある 森郷埋立地を再び開き，同様に 9 月 1 日から 11 日の間, 家庭ごみを埋め立てた。

[担当 : 大柣俊和]

\section{3 豪雨災害}

(1) 8 月 6 日豪雨災害（1993 年）

この豪雨災害については，情報の収集を継続している ところであり, 鹿児島市消防防災課が被害に関する情報 を有している。基本的には, 災害廃棄物は 3 所の仮置 き場に一度収集された後，夜間に最終処分場に搬送され， 廃裹物の全量が埋立処分されている。災害廃棄物の処分 量は処分場への搬入車両台数およびその大きさにより把 握されているが，篁密な意味で正確には把握されていな い。また， 1 ヶ月後の 1993 年 9 月 6 日には台風 13 号が 発生し,この豪雨災害に限定した災害廃裹物の発生量を 把握することは困難な状況にある。 [担当：前野祐二] 


\section{4 その他の自然災害}

（1）福岡市異常渇水 (1994 年) ${ }^{11)}$

1994 年夏は西日本を中心に全国的な異常渴水に見舞 われ，加えて各地で観測史上最高の気温を観測した。各 地で給水制限が実施され, 市民は断水に備えて「渴水商 品」であるプラスチック製容器, ビニルホース, ラップ, ひしゃくなどを睡入し, プラスチック製容器の商品不足

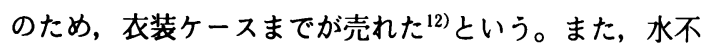
足のためペットボトル入りの飲料水が良く売れ, 学校給 食では食器洗浄に水を使用しないように, 皿の上に食品 用ラップを巻くなどの工夫がされた ${ }^{13)}$ 。飲食店において, 使い捨ての食器を使用したことなどは, 筆者も経験した ことである。このような状況から排出されるごみ質は変 化し, 清掃工場での発熱量の増加, 断水下での場内用水 の確保など，ごみの処理に様々な影響を及ぼすことが眯 念された。そこで, 福岡市を始め, 渴水の程度が大き かった都市について，それらの影響を調查することにし た。

福岡市では 1994 年の年間降水量が $891 \mathrm{~mm}$ と, 1890 年以来 105 年間の観測史上最低を記録した。1994 年 8 月 4 日より給水制限が始まり, 解除されたのは本年の 6 月 1 日である。福岡市は 1978 年にも大渇水（年間降水 量 $1,138 \mathrm{~mm}$, 給水制限日数 278 日間）を経験しており, これを教訓に市は節水要綱を定め, 市民の節水意識の高 揚, 節水機器の普及, 雑用水道の普及, 漏水防止対策な どの節水型都市づくりを積極的に行ってきている。

福岡市には 4 つの清掃工場（東部工場, 第 2 工場, 南 部工場, 西部工場) が建設されており, 南部工場は 1978 年 4 月に着工しており, 折しも大渴水の最中で あった。そのため節水型の清掃工場へと設計変更がなさ れ, 節水型機器の導入, 処理排水の再利用などの対策が 取られた。その後に建設された西部工場においては，さ らに徹底した節水対策がなされている。このような背景 から，1994 年の異常渴水による清掃工場稼働への問題 は特になかったとのことである。福岡市の清掃工場にお ける水の使用状況は, 上水は主に飲料水などの生活用水 やボイラー用水に使用し, 機器冷却水などのプラント用 水は井戸水を極力使用して, 上水使用量の低減がなされ ている。異常渴水に対しては, (1)下水処理水の有効利用, (2)井戸水の利用, (3)减湿装置（排ガス中の水分を回収す る。）の機能強化, (4)冷房の節減, 風呂水の節水, 清掃 用散水の制限, などが実施された。その結果, 1994 年 8 月以降 1995 年 3 月までの 4 つの工場での上水使用量 は対前年度同期比で $73 \%$ ，また，ごみ 1 ton を焼却す るのに要する上水使用量は $69 \%$ となっている。1994 年 度のごみ 1 ton を焼却するのに使用した水量は, 西部工
場を除く 4 つの工場で 1.03 ton/ごみ ton, 西部工場で は 0.46 ton/ごみ ton と限界に近い（一般的には, 2 ton/ごみ ton といわれている。）までの節水対策がはか られていることがわかる。

断水によるごみ質への影響が谧念されていたが，ごみ 組成分析からはその影響は見られていないとのことで あった。

[担当：島岡隆行]

\section{4.おわりに}

本調查研究をきっかけに，わが国の災害事例を調べる につれ，自然災害発生頻度の多さに驚かされる。これら の災害に伴い，多かれ少なかれ災害廃裹物が発生してい る訳である。また，阪神・淡路大震災により発生した災 害廃棄物の量が明らかになるにつけ, 家屋の解体に伴う 廃棄物の発生量が, 日々排出される廃棄物に比べて極め て多いことが認識されつつある。手元にある新聞記事 ${ }^{14)}$ には,「住宅一軒解体，新築すると，廃材は家庭のごみ 34 年分」と記されている。災害廃棄物の発生量や処理 の状況が克明に記録され，活用されていたならば，災害 廃裹物（建設廃材）の再利用方法やリサイクル技術が開 発されていたものと思われる。阪神・淡路大震災からの このような教訓をとに, 自主研究のメンバーが担当し ている災害事例について継続的に調査を行い，問題点の 抽出や自然災害間の様々な視点から比較検討を行うつも りである。

最後に, 調查にあたっては, 兵庫県保健環境部岡崎 俊忠氏を始め, 自治体の多くの方々にお世話になりまし た。ここに記して深謝いたします。

\section{丢考文献}

1）都市清掃，特集「特殊噮境での清掃事業」、Vol. 35, No. 130, pp. 2-61 (1982), 例えば, 田中勝ら：災 害時におけるごみ処理対策, 都市清掃, Vol. 35 , No. 130, pp. 7-21（1982），他 8 編

2）建設省土木研究所：昭和 57 年長䗁水害及び昭和 58 年 山陰水害における路上障害物の除去方法に関する研究, 土木研究所資料, No. 2417 (1986)

3）黒田重徳ら：夕么眝水池流木の木炭化による再資源化, 土木学会論文集, No. 503/II-29, pp. 197-205（1994）

4) Hubert W.F. Bunce et al. : Economic feasibility of utilizing logging slash and fire-killed timber for energy, Energy Biomass Wastes, Vol. 15, pp. $233-272$ (1991)

5 ) Berrin Tansel et al. : Building performance and structural waste generation by Hurricane Andrew, Housing Science, Vol. 18, No.2, pp.69-77 (1994) 
6)後藤敏子：都市の災害とごみ処理，建築設備と配管工 事, Vol. 31, No. 3, pp.64-67 (1993)

7) Bill Knapp: All shook up: Dealing with disasters, World Wastes, Vol. 37, No. 7, pp. 22 - 32 (1994)

8) 廃裹物学会研究委員会自主研究グループ編 : 災害等へ の特殊環境における廃棄物処理の在り方, 災害廃棄物 処理現地調查報告書 (1995)
9 ）八戸市企画部,生活環境部内部資料
10）仙台市内部資料
11）福岡市環境局内部資料（1995）
12）朝日新聞 朝刊, 1994.8. 4
13）朝日新聞 朝刊, 1994.9.3
14）読売新聞 朝刊, 1994.5.11

\title{
An Investigation on Solid Waste Generations by Natural Disasters and Disposal Measures
}

\author{
Takayuki SHimaoka \\ Department of Civil Engineering, Faculty of \\ Engineering, Fukuoka University \\ ( 8-19-1, Nanakuma, Jonan-ku, Fukuoka, 814-80 Japan)
}

\begin{abstract}
The Great Hanshin-Awaji Earthquake Disaster has caused significant damage to structures and generated approximately 18.5 million tons of earthquake waste. This earthquake was the first major one in the Hanshin District. For this reason, much effort was required for the collection, cleanup, and disposal of debris, and the enormous amount of debris generated by pulling down structures such as residences and buildings was seen in a new light. In order to let this be a lesson, an investigation on solid waste from natural disasters has been started by the younger membere of the Japan Society of Waste Management Experts. This paper reports on the situation of solid waste management for earthquake waste from the Great Hanshin-Awaji Earthquake Disaster in the stage of initial revival and other huge natural disasters which have occurred in recent years.
\end{abstract}

Key words : natural disaster, the Great Hanshin-A waji Earthquake Disaster, earthquake waste, debris, disposal measures 